\title{
Designing Power Wave AUTOMASS (Automatic Maritime Security System) As Effort to Prevent IIllegal Fishing
}

\section{Massus Subekti, M. Rif'an, and Daryanto}

Faculty of Engineering, University of Jakarta, Jakarta, Indonesia

\section{Abstract}

This research aims to provide solution on illegal fishing problem in Indonesia. The solution offered is creating Power Wave Automass as automatic maritime security system. Power Wave Automass is an equipment which is powered by converting ocean wave energy into renewable electricity energy. Expected outcomes of this research is creating capable converting process for the equipment in order to utilize vertical ocean wave energy into electrical energy as an alternative and renewable energy resource in Indonesia. The research method used in this study is a design analysis including

Corresponding Author:

Massus Subekti

masus@unj.ac.id

Received: 11 January 2019

Accepted: 14 February 2019

Published: 25 March 2019

Publishing services provided by

Knowledge E

(c) Massus Subekti et al. This

article is distributed under the

terms of the Creative Commons

Attribution License, which

permits unrestricted use and

redistribution provided that the

original author and source are

credited.

Selection and Peer-review under the responsibility of the 3rd ICTVET 2018 Conference Committee.

\section{G OPEN ACCESS}

Study Literature, Wave data retrieval, and BMKG satellite image data, system design, determination of design size, simulation and analysis of the reliability of system design.

Keywords: wave energy, alternative energy, illegal fishing

\section{Introduction}

As archipelago country, Indonesia has thousands islands among equator lines, from Sabang to Merauke, with 5,9 million $\mathrm{km}$ square width, consists of 3.2 million $\mathrm{km} 2$ territorial space and $2.7 \mathrm{~km} 2$ Exclusive Economic Zone and 2/3 of the territory is sea, the area does not include the continental shelf. This makes Indonesia the largest archipelagic country in the world [1]. Certain, with that fact, Indonesia has many resources. But, unfortunately, those resources failed to enhance fisherman's life quality, because there are many illegal fishing which done by foreign boat. Illegal fishing activities carried out by state fishermen from countries that are illegal. Through various modus operandi of fishermen released in Indonesia and then traded outside Indonesia with multiple profits. Illegal arrest [2] data from Auditing Board of Republic Indonesia, in 2013, showed potential income from fishery is 365 trillion rupiah for a year, but, because of illegal fishing, decrease, regarding on Ministry of Marine and Fishery, to 65 trillion rupiah for a year. It means hundreds trillion rupiah missing [3]. 
Government already do efforts like arresting, burning, and drowning every boats which did illegal fishing. Because this needs good navy quantity, what government do is ineffective, and also can start political conflict with country of the boat comes from. In order to solves the problem, there must be an equipment to track every foreign boat movement in Indonesia territory, and the equipment is Power Wave AUTOMASS (Automatic Maritime Security System) which utilized Acoustimeter Radio Frequency Detector to detect radio signal that the boat use. This system energized by electricity from converting wave energy. Placing Power Wave AUTOMASS in whole Indonesia's ocean and connect them with each other can monitor foreign board well. This monitoring will help government to reduce illegal fishing in Indonesia.

The problem at the moment is how to design a sea wave power plant needed by AUTOMASS which can detect ships well in the Indonesian ocean. This technology, expected, can enhance fisherman life quality and develop Indonesia fishery sector, thus, nation compete skill increase, like government has planned. This research is develop the previous research about ocean power plant which combine wave power plant [4] and Wave Powered Generator from Raichlen et al [5] and Wave Motor patent from Mordechai Welczer et al [6].

Ocean power plant system is converting ocean vertical wave become kinetic energy to pump water into reservoir in order to whirl turbine which connected to generator. This system place pump piston and pump cylinder under ocean. Generator connect directly to load. On AUTOMASS Power Wave, electricity generate from ocean vertical wave, which place pump cylinder and connect to pontoon and pump piston under ocean. Electricity will scan radio signal and thermal boat to monitoring foreign boat in Indonesia's ocean.

\section{Methods and Equipment}

\subsection{Methods}

The research method used in this study is a design analysis including Study Literature, Wave data retrieval and BMKG satellite image data, system design, determination of design size, simulation and analysis of the reliability of system design.

- Pre-Research, This stage identifies the problem based on the background of the problem to be resolved. These general problems include the need for offshore electricity development that can be used as an electricity source for tracking the movement of foreign vessels in the archipelago that do illegal fishing 


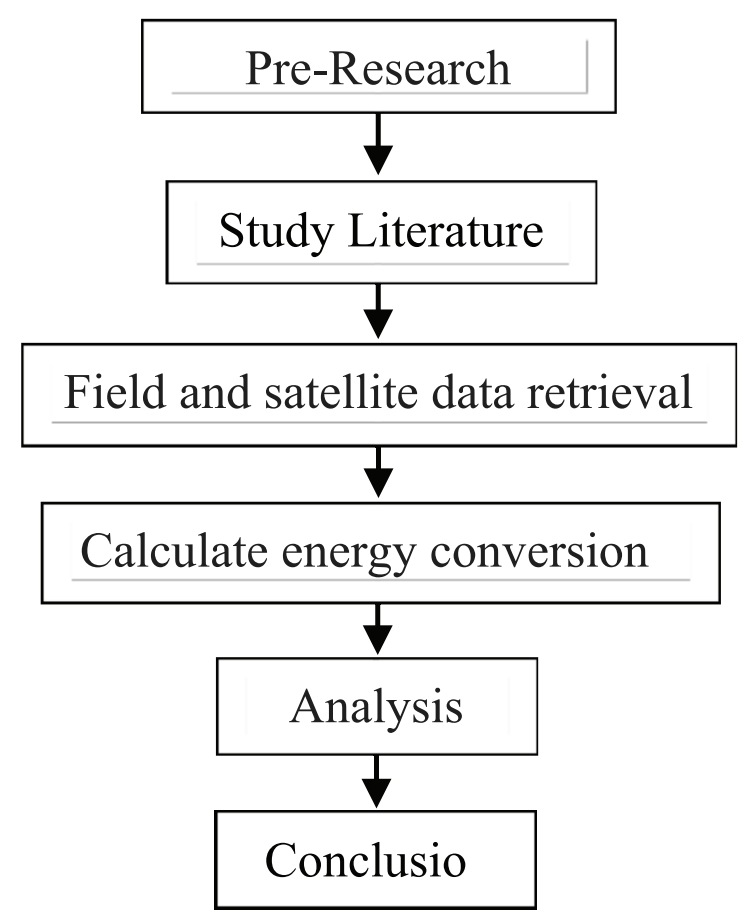

Figure 1: Research stage.

- Study Literature, This stage conducts a literature study of the types of plants that are most suitable as a source of electricity for tracking the movement of foreign vessels in the archipelago that do illegal fishing

- Field and satellite data retrieval, his stage collects satellite data from BMKG, the initial survey location for the application of AUTOMASS Power Wave

- Calculate energy conversion, his stage performs a mathematical calculation of the conversion of wave energy into motion energy, pressure and electrical energy.

- Analysis, This stage analyzes the electrical energy generated by high data and wave periods obtained from satellite imagery, the Meteorological and Geophysical Agency and direct measurements with a predetermined system size.

- Conclusion, This stage concludes the amount of electrical energy generated as an electricity source for AUTOMASS Power Wave.

\subsection{Equipment}

The equipment used in this study is a generating unit consisting of pontoons, reservoirs, turbines and generators. measurement of wave height using a slide rule, measurement of wave period using stopwatch 


\section{Results}

Power Wave AUTOMASS is a system that detects radio waves and heat by using energy from ocean wave energy. The existence of the ship can be detected by using the Radio Frequency Detector Acoustimeter to detect the radio waves used and the Infrared Sensor to detect heat, the information about the next shipment will be sent to a data center through a network of radio waves connected between Power Wave AUTOMASS

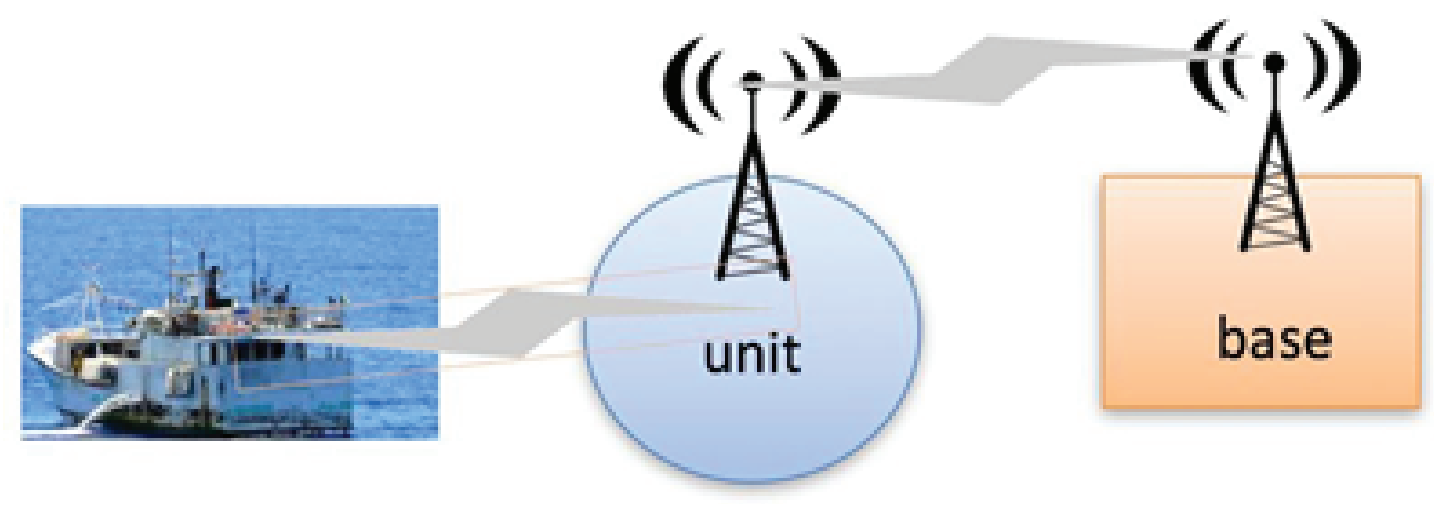

Figure 2: Ship Wave Detection Design in Power Wave AUTOMASS.

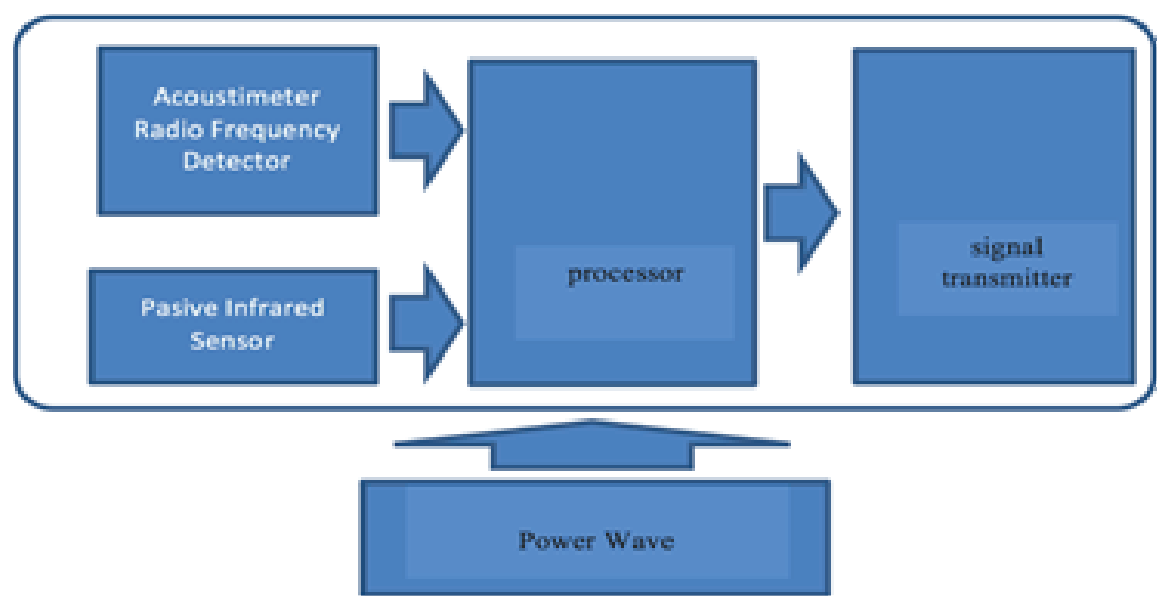

Figure 3: Block diagram of the ship detection unit in Power Wave AUTOMASS.

While the electrical energy needed by the system is obtained from ocean wave energy by converting vertical energy waves into motion energy to pump seawater into the reservoir pressurized to rotate the water turbine connected to the electric generator by placing the pump piston directly connected to the pontoon and the pump cylinder mounted on the base the sea. 


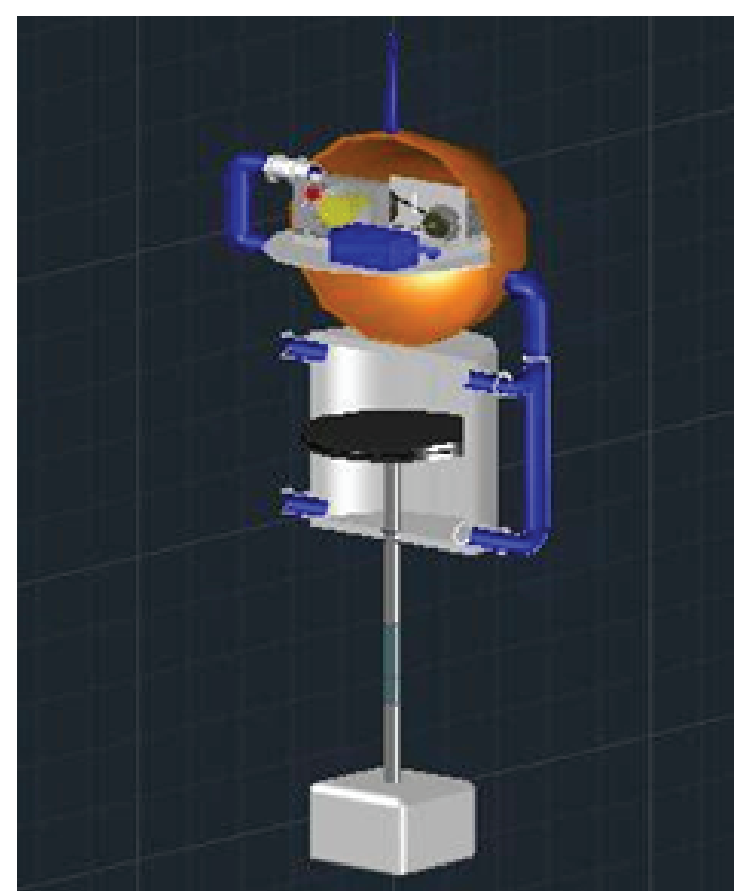

Figure 4: Power Wave AUTOMASS design.

TABLE 1: Calculation simulation.

\begin{tabular}{|c|c|c|c|}
\hline KONSTANTA & SYMBOL & VALUE & UNIT \\
\hline phi & $\pi$ & 3,14 & - \\
\hline Sea water type density & $\rho$ sea wal & 1.030 & $\mathrm{~kg} / \mathrm{m} 3$ \\
\hline gravity & $g$ & 9,8 & $\mathrm{~m} / \mathrm{s} 2$ \\
\hline wave height & $\mathrm{h} / 2$ & & $m$ \\
\hline wave period & $T$ & & $\mathbf{s}$ \\
\hline pontoon volume & V-pon & 15 & liter \\
\hline pontoon weight & & 76 & $\bar{N}$ \\
\hline D piston & D1 & 8 & inchi \\
\hline length of motion & p-langk & & $\mathrm{m}$ \\
\hline Speed of water entering & v1 & 0,25 & $\mathrm{~m} / \mathrm{dt}$ \\
\hline piston pressure & P1 & 2.334 & $\mathrm{~N} / \mathrm{m} 2$ \\
\hline speed of water coming out & v2 & 16,0 & $\mathrm{~m} / \mathrm{dt}$ \\
\hline out pressure & P2 & 149.346 & $\mathrm{~N} / \mathrm{m} 2$ \\
\hline water discharge & & 0,0081 & $\mathrm{~m} 3 / \mathrm{s}$ \\
\hline height & $t$ & 14,8 & meter \\
\hline $\mathrm{H}_{\text {net }}$ & $:$ & 14,8 & $\mathrm{~m}$ \\
\hline$Q_{\text {net }}$ & : & 0,008 & $\mathrm{~m} 3 /$ det \\
\hline
\end{tabular}

\section{Discussion}

The results of the study will only be presented in the field of power wave design that will be used as a source of electrical energy for AUTOMASS 
- Constants

$\operatorname{Pi}(\pi)=3,14$, gravity $9,8 \mathrm{~m} / \mathrm{s}^{2}$ and sea water density $=1,030 \mathrm{~kg} / \mathrm{m}^{3}$

\section{- Calculation Assumptions}

Maximum wave height $(h)=1 \mathrm{~m}$, wave period $(T)=4 \mathrm{~s}$, the wave is assumed linear, turbine efficiency of $60 \%$, generator efficiency of $80 \%$, transmission efficiency of $90 \%$.

- System Size

Ponton volume 50 liter, Piston diameter $\left(D_{1}\right)=8$ inch diameter output $\left(D_{\text {out }}\right)=1$ inch, the length of the piston step $=100 \mathrm{~cm}$.

- Buoyant force

with a volume of 15 liter pontoons produce a buoyancy force of $76 \mathrm{~N}$

- Incoming water speed (V1)

Incoming water speed is pump stride length per unit time, the water inlet velocity of $0.25 \mathrm{~m} / \mathrm{s}$.

- Pump inlet pressure (P1)

With 8 inch pipe diameter $(0.203 \mathrm{~m})$, the size of the piston surface area is 0,032 $\mathrm{m} 2$. Because the pump inlet pressure is defined as the ratio of force to the surface area of the piston pump, the size of the pump inlet pressure of $2.334 \mathrm{~N} / \mathrm{m}^{2}$.

- Water exit speed (V2)

1-inch diameter pipe output $(0,025 \mathrm{~m})$, the amount of pump output surface area is $0,001 \mathrm{~m} 2$. Because of the magnitude of the speed of the water out is defined as the product of the ratio of the surface area of the piston (A1) and the speed of the water inlet (V1) with a surface area of the pump exit $(\mathrm{A} 2)$ or $\mathrm{V} 2=(\mathrm{A} 1 \mathrm{xV1}) / \mathrm{A} 2$, then the amount of water exit velocity of $16 \mathrm{~m} / \mathrm{s}$.

- Exit pressure pump (P2)

The magnitude of the pressure pump is a comparison of time pressure and the piston surface area to the surface area of the pipe exit. Exit pressure pump is $149.346 \mathrm{~N} / \mathrm{m}^{2}$.

- The water discharge (Q)

Water discharge is defined as the volume of water displaced into the reservoir per unit time. discharge of water flowing into the reservoir was $0.0081 \mathrm{~m} 3 / \mathrm{s}$, equivalent to a potential water energy of $14.8 \mathrm{~m}$. 


\begin{abstract}
- Electric Output
with water discharge of $0.008 \mathrm{~m} 3 / \mathrm{s}$, water level equal to $14.8 \mathrm{~m}$ and turbine efficiency of $0.6 \%$, the turbine output is $0.7 \mathrm{~kW}$. With generator efficiency of $70 \%$ and transmission efficiency of $90 \%$, then the electricity that can be generated is 509 watts
\end{abstract}

\title{
5. Conclusion
}

The results of the calculation of the power wave design with volume 15 liter ponton, piston diameter 8 inch, length of step $1 \mathrm{~m}$ assuming wave height $1 \mathrm{~m}$, wave 2 period produces electrical energy of 509 watts, this energy can be used as a source of electricity for Automatic Maritime Security System (AUTOMASS) To Prevent Illegal Fishing.

\section{References}

[1] Lasabuda, Ridwan. (2013). Development of Coastal and Oceanic Areas in the Perspective of the Republic of Indonesia, Regional Development in Coastal and Ocean in Archipelago Perspective of The Republic of Indonesia. Platax Scientific Journal, vol. 1-2, January 2013. pp. 92-101.

[2] Muhammad, Simela Victor (2012). Illegal Fishing In Indonesian Waters: Problems And Efforts To Handling It In Bilateral Area. Journal of Politicia. Vol. 3 No. 1, Mei 2012. Pp. 59-84.

[3] Ruatam, Ismah. (2015). The challenges of ALKI in realizing Indonesia's ideals as a world maritime axis. Indonesian Perspective. Vol. 1 No. 1, January- June 2015. pp 121.

[4] Subekti, Massus. 2009. Rancang Bangun Prototipe Pembangkit Listrik Tenaga Air Gelombang Laut (PLTA-GL). Prosiding Seminar Nasional Teknologi Industri (Teknoin). Yogyakarta: Universitas Islam Indonesia.

[5] Raichlen et al. (1986). Wave Powered Generator. United States patent, 4.594.853, June $17^{\text {th }} 1986$

[6] Welczer, Mordechai et al. (1978). Wave Motor. United States Patent, 4.076.463, February, $28^{\text {th }} 1978$ 